頸椎後縦䩲带骨化症の術後追跡調査

\begin{tabular}{|c|c|c|c|c|c|}
\hline 斉 & 庇 & & 稔・河 & 合 & 伸 \\
\hline 今 & 釜 & 梊 & 男・小 & 田 & 裕 \\
\hline 村 & 上 & 哲 & 期 - 野 & 村 & 耕 \\
\hline 时 & 中 & & 浩 & & \\
\hline
\end{tabular}

\title{
Follow-up Study of Cervical Myelopathy due to Ossification of the Posterior Longitudinal Ligament
}

by

\begin{abstract}
Minoru Saika, Sinya Kawai, Tetsuo Imagama, Hirotsugu Oda, Tetsurou Murakami, Kouzou Nomura and Hiroshi Tanaka

Department of Orthopedic Surgery, Yamaguchi University School of Medicine, Yamaguchi, Japan (Director: Prof. S. Kawai)
\end{abstract}

\begin{abstract}
Post-operative long-term results of the cervical myelopathy due to ossification of the posterior longitudinal ligament were studied. Fifty-six cases consisting of 41 males and 15 females were discussed. Their age ranged from 38 to 73 years (average; 54.6 years old) at the time of operation. Their follow-up periods were more than one year and up to 15 years (average; 5 years and 6 months).

Their overall results were satisfactory: that is, excellent and good results were obtained in $73 \%$ of the cases at the time of discharge, and in $70 \%$ at the time of followup study. As for the transition of the results from the time of discharge to those of follow-up, the results were better in $39 \%$, unchanged in $29 \%$ and worsened in $32 \%$. However, the degree of changes in symptoms and signs were not significant, indicating that the results were stable after surgery.

The episode of trauma (mostly frequent minor trauma) and duration of myelopathy significantly effected on the final results, and the pre-operative clinical grade of the neurological impairment and age at the time of surgery were the next.
\end{abstract}

昭和 37 年以降, 山口大学において 手術的治療を行 なった頸椎後縦勒带骨化症（以下 OPLL）に対し，術 後追跡調查を行ない，術後の長期経過，成績飞関与す る因子，覀化例等につき検討した.

\section{対象及び方法}

炤和 37 年以降, 䫊部脊随症 のため 手術的治療を行 なった頸椎 OPLL 症例中, 術後の経過推察が可能で あった 56 例を対象とした. なお，胸，腰椎の OPLL や OYL が症状に関与している症例は除外した. 観察 期間は, 最低 1 年より最辰 15 年, 平均 5 年 6 力月, 性別は男性 41 例，女性 15 例，手術洔年令は 38 才よ
り 73 才，平均 54.6 才であった.

成績の判定は，日整会判定基準に基づき，平朴法に 準じて

$$
\text { 改善率 }=\frac{\text { 退院封 (または調洔) 点数 }- \text { 術前点数 }}{17} \times 100
$$

より改善率を算出し，75\%以上を假，74〜50\%を良， 49 20\%を可，19〜0\%を不良，0\%以下を悪化，と して評洒した，そして，傁，良を改善群，可，不変， 悪化を改善不良群とし，成績に影響すると思狆るる因 子,
1)手術特年令
2) 罹病期間 
3）外傷歴

4) 術前点数 (術前重症度)

5）残余脊柱管塽窄率

6）残余脊柱管前後柊

7）脊柱管前後径

8）骨化型

9）術後の骨化增大

10）手術法

につき，退院時と調査封の成績を比較榆討した.さら に，退院時から調査時にかけての成績の推移を，成績 向上群, 低下群の 3 群に分類し, 各因子が成績の推移 に関与しているか否功検討した。

$$
\text { 結果 }
$$

\section{1. 総合成績}

術後平均約 2 力月の 退院洔 の成績は, 優 16 例 29 $\%)$ ， 之改善群が 41 例 $73 \%$ を占め，退院後平均 5 年 6 力月の調方時の成績は，優 20 例 (30\%)，良 19 例 (34\%), 可 8 例 (14\%), 不変 6 例 (11\%), 悪化 3 例 (5\%), 之改善群が 39 例（70\%）を占め，ほぼ満 足できる結果之思われる (図 1).

成績の推移は，成績向上 22 例 (39\%\%)，安定 16 例 $(29 \%)$ ，低下 18 例 (32\%)，となり，約 $2 / 3$ の症 例は成績の変動を示すが, その程度は平均 1.4 点であ り, 大半は $1 \sim 2$ 点の変動にとどまっており, 概して 術後の成績は安定している書思われる.

2. 成績之各因子との関係

1) 手術時年令

年代別で，退院時及び調査時成績に有意差を認めな い. 50 才未満と 50 才以上の群で みると，退院侍 50 才未満に明らかに多かった改善群 13 例（86\%）が， 調査時には 10 例（69\%）に減り 50 才以下之ほぼ同成 績を示す（表 $1 ， a ）$.

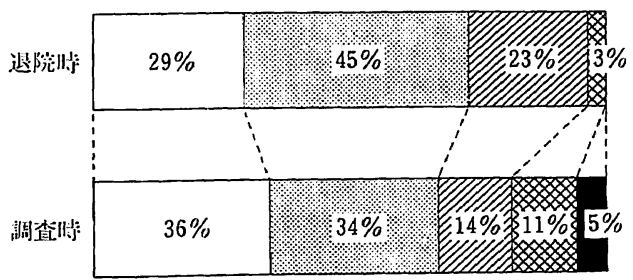

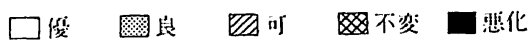

図 1 総合成糾

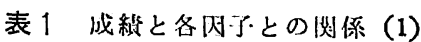

a. 于街猔年令

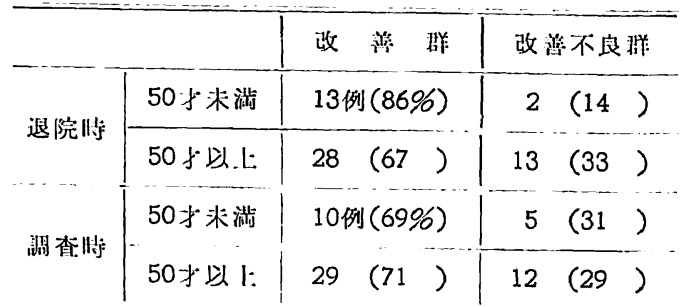

b. 椎坊期間

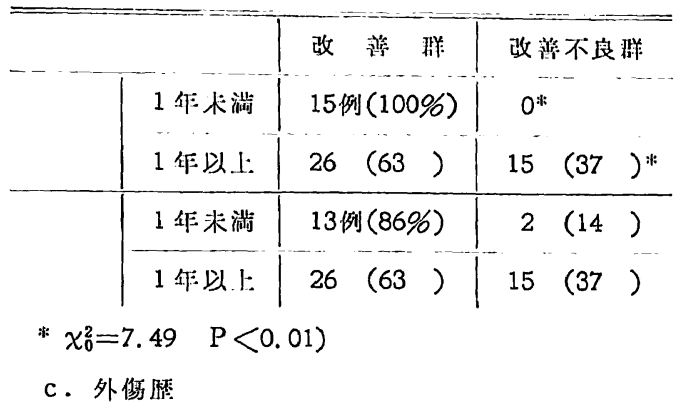

\begin{tabular}{|c|c|c|}
\hline & 改 滵 群 & 改蓞不良沜 \\
\hline （一）群 & 37 例 (80\%) & $9(20) *$ \\
\hline (+) 群 & $4(40)$ & $6(60) *$ \\
\hline (一) 群 & 35 例 (76\%) & $11(24 \%) * *$ \\
\hline$(+)$ 群 & $4(40)$ & $6(60)^{* k * k}$ \\
\hline
\end{tabular}

$\left.* \chi_{0}^{2}=6.85 \quad \mathrm{P}<0.01\right)$

**: $\left.\chi_{0}^{2}=5.06 \quad \mathrm{P}<0.025\right)$

\section{2) 䍜病期間}

1 年未満亡 1 年以上の 2 䂜において,

1 年未満では, 改普群が退院特 15 例 (100\%), 調

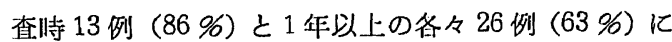
比し，有意差をむって好成綃を示す（非 $1 ， b$ ）.

3）外傷歷

外傷(群では，改善群が退院時 37 例 (80\%), 调查 時 35 例 (76\%), 之外伤 (+) 群の各々 4 例 (40\%) に比し，有意差をむって好成縜を示す（表 $1 ， \mathrm{c}$ ). な おこてで述べる外伤は, 柽い柽倒頻回に版わった怪徽 なものを示し，脊能損倠と思われる外仿は除外してい る.

4) 術前点数

12 点以上の群では，改善群が退院時 12 例（92\%)， 
表 2 成䍀と各因子との関係（2）

d. 術前点数

\begin{tabular}{|c|c|c|c|}
\hline & & 改 㦈 群 & 改㗝不良碓 \\
\hline \multirow{2}{*}{ 退院琮 } & 12 点以上 & 12例 (92\%) & $1(8)$ \\
\hline & 12点未满 & $29(67)$ & $14(33)$ \\
\hline \multirow{2}{*}{ 調查洔 } & 12点以上 & 11例 (85\%) & $2(15)$ \\
\hline & 12点米渋 & $28(65)$ & $15(35)$ \\
\hline
\end{tabular}

e，脊柱管前後径

\begin{tabular}{|c|c|c|}
\hline & 改 善 群 & 改善不良群 \\
\hline $14 \mathrm{~mm}$ 以上 & 20 例 (65\%) & $11(35)$ \\
\hline $14 \mathrm{~mm}$ 未满 & $21(84)$ & $4(16)$ \\
\hline $14 \mathrm{~mm}$ 以上 & 20 例 (65\%) & $11(35)$ \\
\hline $14 \mathrm{~mm}$ 米临 & $19(76)$ & $6(24)$ \\
\hline
\end{tabular}

f。手術法

\begin{tabular}{c|c|c|cc}
\hline & 改善 群 & 改善不良群 \\
\hline & 前方法 & 10 例(77\%) & 3 & $(23)$ \\
\hline & 後方法 & $31(72)$ & 12 & $(28)$ \\
\hline & 前方法 & 8 例(62\%) & 5 & $(38)$ \\
\hline & 後方法 & $31(72)$ & 12 & $(28)$
\end{tabular}

調查时 11 例 (85\%)，と 12 点未満の各々 29 例（67 \%)，28例（65\%）飞比し良い傾向が みられる（表 $2, \mathrm{~d})$.

\section{5）狭窄摔}

㹨窄の程度により成績に有意差を認めない。

6) 有效脊柱管前後径

有效脊柱管前後径の程度により成績に有意差を認め ない.

7）脊柱窄前後径

脊柱管前後径の程度により成績に有意差を認めない が, $14 \mathrm{~mm}$ 以上の群で, 改善群が退院封, 調查時共に 20 例 $(65 \%)$ ， 之 $14 \mathrm{~mm}$ 未満の各々 21 例 (84\%), 19 例（76\%）より悪い（表 $3 ， e$ ).

8）督化型

骨化型は，限局型 4 例（7 \%)，分節 型 17 例（30 $\%$ \%)，速続型 16 例 (29\%)，混合型 19 例 (34\%) で あるが，骨化型別で成績に有意差を認めない。
表 3 成絽の推移

a. 外攸歷

\begin{tabular}{|c|c|c|c|c|c|}
\hline & 垧 & 少 & 定 & 低 & 下 \\
\hline $\begin{array}{c}(-) \\
(+)\end{array}$ & $\begin{array}{c}22 \text { 例 }(48 \%) \\
0\end{array}$ & $\begin{array}{r}12 \\
4\end{array}$ & $\begin{array}{l}(26 \\
(40\end{array}$ & $\begin{array}{r}12 \\
6\end{array}$ & $\begin{array}{l}(26 \\
(60\end{array}$ \\
\hline
\end{tabular}

b．脊柱管前後径

\begin{tabular}{r|r|rr|rr} 
& 向 上 & 安 & 定 & 低 & 下 \\
\hline $14 \mathrm{~mm}$ 以上 & 11 例 $(35 \%)$ & 7 & $(23)$ & 13 & $(42)$ \\
$14 \mathrm{~mm}$ 来满 & $11(44)$ & 9 & $(36)$ & 5 & $(20)$
\end{tabular}

9）骨化堌大

退院時と 調査持のレ線写真がそろっている44 例に ついてみると，骨化增大のあるあの 19 例 (43\%)，な いむの 25 例 $(57 \%)$ である．骨化增大の有無を骨化 別でみると，限局型 4 例中 1 例 (25\%), 分節型 17 例 中 2 例 (12\%)，逨続型 16 例中 10 例（63\%)，混合 型 19 例中 6 例 $(32 \%)$ ，之なり，連続型，混合型に八 く, 手術法でみると, 前方法 13 例中 2 例 (15\%), 後 方法 43 例中 17 例 (40\%), となり，後方法に多い. しかし，骨化增大の有哭で，成績に有意差を認めな い.

\section{0）手術法}

手術は，13 例（23\%）飞前方法を，43例 (77\%) に後方法を行なっている. 手術法別に成績をみると， 前方法では, 改善群が退院封 10 例 (77\%), 調查時 8 例 $(62 \%)$ 之減少しているが，後方法では退院時，調 査封共に 31 例 (72\%), 習安定している（表 $2, f)$.

3. 成績の推移

総合的に，成績向上 22 例 (39\%)，安定 16 例（29 \%)，低下 18 例（32\%）である. 日整会点数の変動を みると, 平均 1.4 点で, 1 2 点の変動を示すあのが大 半を占める.

成績の推移について，各因子別に検討すると，明ら かに有意差を示すむのは, 外傷歴であり, 外傷 $(+)$ 群は向上傾向をまったく認めず， 6 例 (60％) が低下 を示す. 脊椎窄前後径については, $14 \mathrm{~mm}$ 以上で 14 $\mathrm{mm}$ 未霂に比し成績低下群が多い傾向を示す（表 3). その他の因子は，成績の推移にほとんぞ影響を 示さない.

$$
\text { 考察 }
$$

頸椎 OPLL は，月本が 1960 年に報告して以来注目 
され，手術的治療が積極的に行なわれ，手術法む飛踓 的に進歩し，乙れに伴い手術成績む问上している．今 回の追跡調查結果では，改善群が镸院洔 $73 \%$, 調查 洔 $70 \%$ とほぼ満足できるあのであり，長期成絽も安 定している. しかし, 頸椎症の術後成績に比較すると 術後成績は不十分な面むあり，頸惟 OPLL では頸惟 症とは異なる何らかの因子が，術後成績に関与.してい るむの之思われる. 頸椎 OPLL の手術成績を庄石す

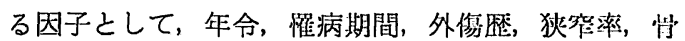
化増大, 術前重症度等が, 第 2 回脊椎外科研究会の集 計，酒句，片岡らにより指摘されている. 我々の追跡 調査結果では, 櫂病期間 1 年未満, 外傷歷 (-) 群が 有意差をむって, よい改善率, 成績向上を示す. 手術 侍年令では，退院洔に50才未満で明らかに改善群が 多いが，調査特には50才以上とまったく差がない， これは，50才未満の中に，他の因子の関与によって成 績の低下を示した症例が含まれるためである，術前点 数については，12点以上で改善群が多い傾向を示す が, 12 点末満の群と有意差なく, 術前点数が低くても 適切な手術により，上い改善率を示すことがうかがえ る. 㹨窄率, 有効脊柱管前後径の程度で成績に差がな く，狭窄が高度であ手術的に十分除圧されているとと がうかがえる. canal stenosis 合件の有無で成績に 有意差を認めず, むしろ合侀しない群に改善不良群が 多い傾向を示すが，乙机は canal stenosis 合例例で は, myelogram で狭窄が強く現われ，後方から十分 除圧されるこ之が多いのに反し，合件しない群では， 術後の骨化增大や頸椎症性変化により, 脊柱管の狭窄 が惹起された症例が含まれているためである，手術法 の前方法之後方法の間に成績の差を認めないが，後方 法のうち，脊柱管拡大術が椎弓切除術よりよい成緽を 示す.乙れは，術式の䢰択が関係しており，OPLLが 小さく狭窄が少ない, dynamic factor の関与が大き い症例には前方法を，OPLL が大きく狭窄が高度で dynamic factor の関与が少ない症例には後方法を， さらにてのうち，比較的若年相には拡大術を，高令者 で全身状態がやや少ったり，極めて麻㾝が重症の症位 には椎号切除術を行っているためと思われる. 退院時 より調査時までの症状の推移については, 約 $2 / 3$ の症 例に点数の変移を認めるが, 大半は $1 \sim 2$ 点の変動に とどまり，おおむ权安定している，症状の推移に対し 明らかに梁関与している因子は，外甥歴のみで，外伤 （十）群では，成績向上をまったく認めない，また，

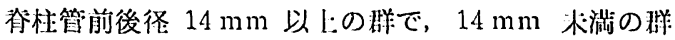
に比し成絬低下傾问を認めるが，その他の因子につい ては特に有意差がなく，条因子の袨合により成絽が変 怔するのではないかと推察される，総合成絽は临足す べきすのであるが，調查㭙 3 点以上の成緽低ドを示し

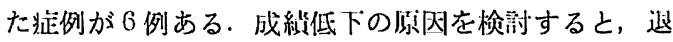

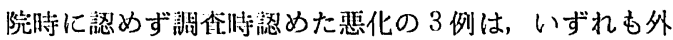
物 $(+)$ 群に属し，てのうち2例は怪度の OPLL 增

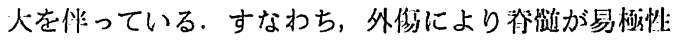
になり，術後症状が一眝的に改谣しても，その後の金 柱管のわずかな変化により㫌状增恶を示すのではない かと思㧈る。他の 3 例中 2 例は，OPLL の增大によ

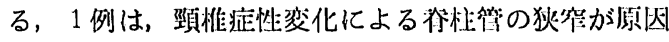

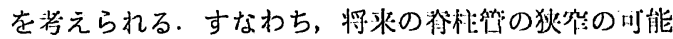
性があることを念顕に手術法を決定することが重管で あると思わ机る。

$$
\text { 結語 }
$$

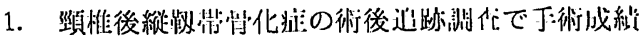
は長期にわたり安定しているてとがわかった.

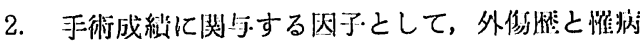

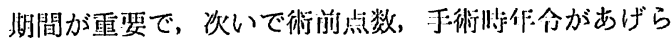
れた.

3. 于術成絬を问上させるには，術後の间化增人や

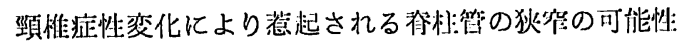
を考愿して沃定することが重装であると思われた。

$$
\text { 文献 }
$$

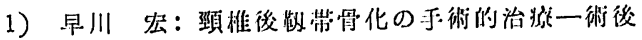
3 年以上経调例飞ついて一. 日悠会志，53：1268, 1979.

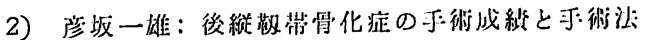
の選択. 臨些外, 10:751-760, 1975.

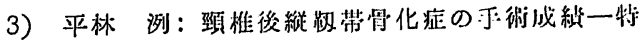
亿手術操作之術後の骨化進展化ついて一. 日整会 誌, 52: 1299, 1978.

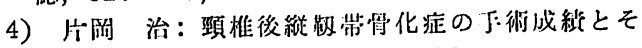
の検討. 啙形外科，29：1-9，1978.

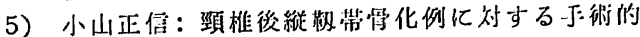

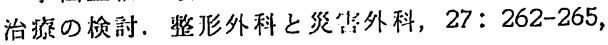
1978.

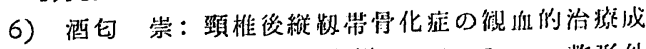

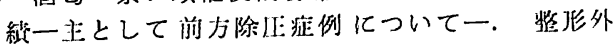
科, $27: 259-269,1976$.

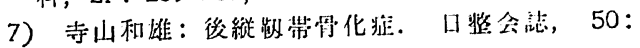
415-442, 1976. 
質 問

硜椎症と OPLL の成績の比較をされていないか

解 答 山口大学 斉鹿稔

頸椎症と OPLL の脣期成縜の比較は今回，行って
いない. しかし, 頸椎症は dynamic factor の関与 が大きく, OPLL であ分布型では同様であるが, 全体 的に OPLL では脊柱管の狄窄の因子があり, OPLL とは術後長期経過は異なるのではないでしょうか. 